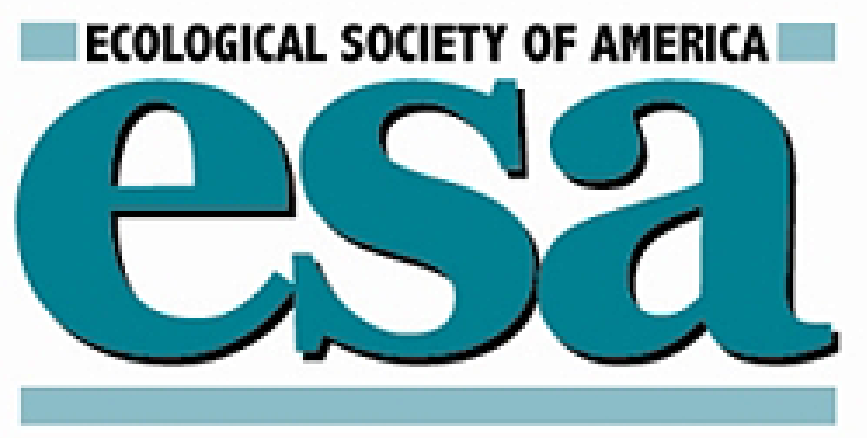

Activity-Specific Metabolic Rates of Free-Living Northern Gannets and Other Seabirds Author(s): V. L. Birt-Friesen, W. A. Montevecchi, D. K. Cairns and S. A. Macko

Source: Ecology, Vol. 70, No. 2 (Apr., 1989), pp. 357-367

Published by: Ecological Society of America

Stable URL: http://www.jstor.org/stable/1937540

Accessed: 30/05/2013 12:05

Your use of the JSTOR archive indicates your acceptance of the Terms \& Conditions of Use, available at http://www.jstor.org/page/info/about/policies/terms.jsp

JSTOR is a not-for-profit service that helps scholars, researchers, and students discover, use, and build upon a wide range of content in a trusted digital archive. We use information technology and tools to increase productivity and facilitate new forms of scholarship. For more information about JSTOR, please contact support@jstor.org. 


\title{
ACTIVITY-SPECIFIC METABOLIC RATES OF FREE-LIVING NORTHERN GANNETS AND OTHER SEABIRDS ${ }^{1}$
}

\author{
V. L. Birt-Friesen, W. A. Montevecchi, D. K. Cairns, ${ }^{2}$ and S. A. Macko \\ Departments of Psychology, Biology, Earth Sciences, and Chemistry, \\ and Newfoundland Institute for Cold Ocean Science, \\ Memorial University of Newfoundland, St. John's, \\ Newfoundland, Canada A1B $3 X 9$
}

\begin{abstract}
Field and activity-specific metabolic rates of 20 free-living Northern Gannets (Sula bassanus; mean mass $=3.21 \mathrm{~kg}$ ) rearing chicks at Funk Island, Newfoundland, were measured using doubly labeled water and activity timers. Field metabolism (FMR) averaged $4865 \mathrm{~kJ} / \mathrm{d}$ or $6.6 \times$ basal metabolism (BMR). Regression analyses indicated a metabolic rate of $144 \mathrm{~kJ} / \mathrm{h}$ while at the nest or on water, $349 \mathrm{~kJ} / \mathrm{h}$ during flight, and $250 \mathrm{~kJ} / \mathrm{h}$ during diurnal time at sea. These metabolic rates are high, probably because of costs of thermoregulation and flapping flight. BMR was slightly lower than predicted. Statistical analyses of metabolic rates of free-living seabirds indicated that rates are elevated in seabirds in cold-water regions and in seabirds that use flapping flight, but do not vary with phylogenetic order. FMR was correlated strongly with both BMR and metabolism at the nest. Population energy models may gain accuracy if metabolic rates are either expressed as multiples of metabolism at the nest or calculated from allometric equations appropriate for the species' activity pattern, oceanographic regime, and foraging mode.
\end{abstract}

Key words: doubly labeled water; energetics; foraging mode; gannet; metabolic rates; seabirds, thermoregulation.

\section{INTRODUCTION}

Ecological energetics models suggest that seabirds consume substantial amounts of marine prey, and that competition may occur between seabirds and commercial fisheries (Furness 1982, Wiens 1984). Large errors in model outputs can result from inaccurate estimates of metabolic rates, especially costs for thermoregulation and activities such as flight (Furness 1978, Weathers et al. 1984, Wiens 1984, Buttemer et al. 1986). Conventional estimates of metabolic rates of free-ranging animals involve multiples of basal metabolic rate (BMR) extrapolated from laboratory to field situations (e.g., Furness 1982, Wiens 1984, Birt and Cairns 1987), but such estimates often deviate widely from direct measurements (e.g., Flint and Nagy 1984). Also, although BMR may vary with phylogenetic order (Rahn and Whittow 1984), latitude, and foraging mode (Ellis 1984), the effects of these variables on other metabolic rates are not known.

The doubly labeled water technique has recently been widely applied to measure field metabolic rates (FMRs) of free-living animals (Nagy 1980, seabird studies reviewed by Ellis 1984, Roby and Ricklefs 1986, Nagy 1987). Furthermore, the development of self-con-

${ }^{1}$ Manuscript received 2 December 1987; revised 6 June 1988; accepted 16 June 1988.

${ }^{2}$ Present address: Science Branch, Department of Fisheries and Oceans, Box 5030, Moncton, New Brunswick, Canada E1C 9B6. tained, lightweight activity timers has enabled determination of the time that seabirds spend flying, pursuit diving, and surface swimming (Kooyman et al. 1983, Prince and Francis 1984, Wilson and Bain 1984, Cairns et al. 1987). Simultaneous use of doubly labeled water and activity recorders permits, for the first time, the measurement of activity-specific metabolic rates of freeranging animals. Information from these two techniques will allow the accurate estimation of population energy requirements.

In the present paper, data from doubly labeled water and a new type of activity timer (Cairns et al. 1987) were integrated to measure FMR and activity-specific metabolic rates in a large, upper-trophic-level seabird, the Northern Gannet (Sula bassanus). Metabolism during flight was predicted to be low due to the gannet's aerial foraging mode and large size (Tucker 1973), but thermoregulatory costs were predicted to be high due to their cold environment and exposed nests (Ricklefs 1974, Ellis 1984). Metabolism measurements of freeliving seabirds were also reviewed to test the hypotheses that (1) metabolic rates of seabirds that engage primarily in flapping flight are higher than those of birds that use primarily gliding flight, (2) seabirds living in cold-water regions have higher metabolic rates than those in warm-water regions, (3) metabolic rates of Procellariiformes birds are lower than those of other seabirds (Rahn and Whittow 1984), and (4) metabolic rates are correlated closely with BMR. 


\section{METHODS \\ Doubly labeled water}

Doubly labeled water was used to measure field metabolic rates (FMRs) of Northern Gannets at Funk Island, Newfoundland $\left(49^{\circ} 46^{\prime} \mathrm{N}, 5^{\circ} 11^{\prime} \mathrm{W}\right.$; 6075 pairs [Nettleship and Chapdelaine 1988]). Studies were conducted in August 1984 and August-September 1985. Forty adults with chicks were caught at their nests at night (to minimize colony disturbance) and given intrapectoral injections of $1 \mathrm{~mL}{ }^{3} \mathrm{HH}^{18} \mathrm{O}$ containing 95 atom $\%{ }^{18} \mathrm{O}$ (i.e., $95 \%$ of the oxygen atoms were ${ }^{18} \mathrm{O}$ ) and $78(1984)$ or $46(1985) \mathrm{kBq} / \mathrm{mL}^{3} \mathrm{H}$. Gannets were held in canvas bags for $4 \mathrm{~h}$ before $3-10 \mathrm{~mL}$ of blood were drawn from a brachial vein into a Vacutainer. Birds were then weighed, banded, fitted with activity timers (see Methods: Activity Data), individually marked with model airplane paint, and released. Individuals were recaught up to three times between 1 and $7 \mathrm{~d}$ after injection, and were bled and weighed again.

Blood samples were vacuum distilled (Wood et al. 1975), and the tritium activities were measured in duplicate or triplicate on 10- (1984) or 100- (1985) $\mu \mathrm{L}$ samples of water in a Beckman LS7500 scintillation counter. One to four $\mathrm{mL} \mathrm{CO}_{2}$ were added to the water that remained from each sample (generally 1-2 $\mathrm{mL}$ ), and the oxygen isotopes of the water and $\mathrm{CO}_{2}$ were equilibrated in a shaking water bath at $25^{\circ} \mathrm{C}$ for $42-46$ h. The $\mathrm{CO}_{2}$ was then cryogenically isolated and its ${ }^{18} \mathrm{O}$ fraction determined in a VG Micromass $903 \mathrm{E}$ mass spectrometer(VG Isogas, Middlewich, England). Background isotope levels were measured on six uninjected gannets. Standards were prepared by diluting $10 \mu \mathrm{L}$ injection solution in $20 \mathrm{~mL}$ distilled water, and were analyzed in triplicate.

$\mathrm{CO}_{2}$ production (millilitres per gram per hour) and water flux (millilitres per kilogram per day) were calculated for each bird for the interval between initial and final captures, assuming that total body water changed linearly between captures as a constant fraction of body mass (Nagy 1980, Nagy and Costa 1980). Total body water was estimated from ${ }^{18} \mathrm{O}$ dilution space (Nagy 1983). FMR (kilojoules per day) was calculated from $\mathrm{CO}_{2}$ production, assuming energy equivalents of 0.0258 or $0.0259 \mathrm{~kJ} / \mathrm{mL} \mathrm{CO}_{2}$ (1984 and 1985 , respectively), and metabolizable energy intake (ME, kilojoules per day) was calculated from water influx, assuming an assimilation efficiency of 0.78 (Montevecchi et al. 1984) and energy equivalents of 9.65 or $9.56 \mathrm{~kJ} /$ $\mathrm{mL} \mathrm{H}_{2} \mathrm{O}$ (1984 and 1985). Conversion rates (kilojoules per millilitre $\mathrm{CO}_{2}$ and kilojoules per millilitre $\mathrm{H}_{2} \mathrm{O}$ ) were calculated from the species composition by mass of regurgitated food collected at the time of doubly labeled water studies (Birt 1987), using nutrient data from Montevecchi et al. (1984) and conversion constants from Nagy (1983). Energy/water conversion rates were corrected for metabolic water production using constants from Nagy (1983). The slight differences in conversions between years resulted from dietary differences.

Measurements of FMR using doubly labeled water become unreliable as final ${ }^{18} \mathrm{O}$ approaches background (Ricklefs et al. 1986, Roby and Ricklefs 1986; P. Tatner, personal communication). To correct for this source of error, all blood samples with ${ }^{18} \mathrm{O}$ enrichments within $2.5 \%$ of background (the maximum error on replicate ${ }^{18} \mathrm{O}$ measurements, see below) were excluded from further analyses.

\section{Reliability of the doubly labeled water assay}

Several tests were done to determine the accuracy of our doubly labeled water assay.

1) ${ }^{18} \mathrm{O}$ measurements were made both in our laboratory and in an independent laboratory $(\mathrm{P}$. Tatner, University of Stirling, Stirling, United Kingdom) on two background and two high-enrichment water samples. Values were identical.

2) The fraction of oxygen atoms that were ${ }^{18} \mathrm{O}$ was measured in duplicate or triplicate on 14 blood and water samples ranging from 0.1999 to 0.2474 atom $\%$. Differences between replicate measurements were within $1.5 \%$, with the exception of one pair that differed by $2.5 \%$ (mean $\pm \mathrm{SD}=0.8 \pm 0.6 \%$ ). To determine the effect of $1 \%$ errors in ${ }^{18} \mathrm{O}$ readings on FMR values, a simulation model was run in which ${ }^{18} \mathrm{O}$ readings of each of 20 gannets (see Results: Metabolic Rates of Northern Gannets) were first increased, then decreased, by $1 \%$, and the percent change in FMR was calculated. Changes of $\pm 1 \%$ in initial ${ }^{18} \mathrm{O}$ were found to produce a maximum error of $3.5 \%$ in FMR; changes of $\pm 1 \%$ in final ${ }^{18} \mathrm{O}$ produced a maximum error of $5 \%$ in FMR.

3) Ideally, background isotope levels should be determined for each animal prior to injection with labeled water, especially in studies involving low ${ }^{18} \mathrm{O}$ enrichments. This procedure greatly increases both handling time and laboratory effort, and is not commonly done. $P$. Tatner (personal communication) determined that use of background levels from birds not used for doubly labeled water measurements did not affect FMR values in European robins (Erithacus rubecula) when the recapture interval was 1-2 d. At least three other seabird studies that used the low-enrichment technique have followed this method (Adams et al. 1986, Costa et al. 1986, Costa and Prince 1987). Background ${ }^{18} \mathrm{O}$ in six gannets ranged from 0.1997 to 0.2001 atom \%. Use of the minimum value in the simulation model (above) produced a maximum change of $4.4 \%$ in FMR; use of the largest value produced a maximum change of $6.6 \%$.

4) Tritium activities were measured in duplicate or triplicate on 14 blood and water samples ranging from 6 to $35 \mathrm{kBq} / \mathrm{mL}$. These readings were generally within $2 \%($ mean $\pm \mathrm{SD}=1.3 \pm 1.0 \%, \max =3.3 \%)$. Errors of $\pm 1 \%$ in tritium activities were determined in the 
simulation model (above) to produce errors of up to $4 \%$ in FMR.

5) The equations used in the present study to calculate FMR and water flux assume that total body water changes linearly between captures as a constant fraction of body mass. Although this assumption may not be strictly valid for gannets, we also calculated FMR and water flux using equations that assume constant body water (Nagy 1980, Nagy and Costa 1980); these values produced mean $( \pm \mathrm{SD})$ changes of only 1.9 $\pm 3.0 \%$ in FMR (median $=1.7 \%$ ) and $2.0 \pm 5.7 \%$ in water flux (median $=1.1 \%)$.

6) FMR was measured on one gannet in 1986 using both the high-enrichment technique (previously validated using respirometry; Nagy 1980, 1983) and the present technique simultaneously. The FMR measurement from the high-enrichment technique was $6 \%$ higher than our mass spectrometer value. Common Murres (Uria alge) that were studied using the present analytical procedure (Cairns et al. 1988) had FMRs similar to measurements for Thick-billed Murres ( $U$. lomvia) (Table 1; Ellis 1984).

These results, as well as various other checks (Birt 1987), indicate that our analytical procedure is reliable and accurate.

\section{Activity data}

Continuous dawn-to-dusk nest watches were carried out on all study birds to record arrival and departure times. Specially devised electronic timers that cumulatively record time spent in or on water (Cairns et al. 1987) were attached to the legs of 23 study birds in 1985. These timers consisted of digital watches modified to turn off during immersion in water. Use of these recorders in combination with nest observations enables measurement of time spent at the nest, on water, and flying. (Gannets do not spend significant amounts of time on land away from their nests; Nelson 1978.) Activity-specific metabolic rates were estimated by least-squares regression of FMR against time budget data. Timers weigh $\approx 0.25 \%$ of adult mass and are estimated to increase the cost of flight in gannets by 1\% (Cairns et al. 1987; J. A. Gessaman and K. A. Nagy, personal communication).

\section{$B M R$}

Oxygen consumption was measured volumetrically on four nonlabeled gannets breeding at Funk Island (August 1986) and six at Cape St. Mary's, Newfoundland $\left(46^{\circ} 50^{\prime} \mathrm{N}, 54^{\circ} 10^{\prime} \mathrm{W}\right.$; June 1986). Gannets were caught at their nests at night and placed in large (62-L), airtight barrels that contained a layer of Drierite and soda lime (to absorb $\mathrm{H}_{2} \mathrm{O}$ and $\mathrm{CO}_{2}$, respectively) beneath a sheet of plastic mesh. Birds were allowed to acclimate to the barrels for 1-3 $\mathrm{h}$ before the chambers were sealed and connected to a thermistor and waterfilled manometer. Changes in temperature and pressure in the barrels were measured for $10-15 \mathrm{~min} . \mathrm{O}_{2}$ uptake was calculated using the equation of Ricklefs et al. (1984) and was converted to energy using a factor of $0.0201 \mathrm{~kJ} / \mathrm{mL} \mathrm{O}_{2}$ (Ricklefs et al. 1984). Changes in atmospheric pressure during $15 \mathrm{~min}$ were assumed to be negligible, and tests in which the pressure in the barrel did not decrease steadily and/or the bird did not remain quiescent were discarded. Because birds were in the rest (nocturnal) phase of their daily cycle, relatively inactive, thermoneutral $\left(16-21^{\circ} \mathrm{C}\right)$ and postabsorptive (3-8 h since dusk and last possible feeding), this value was used as an estimate of BMR. Although this technique has not been validated using open system respirometry and may not be as accurate as other techniques, it has been found to yield results similar to predictions from allometric equations (e.g. Cairns et al. 1988, see Discussion: Metabolic Rates of Northern Gannets), and similar techniques have been validated (Ricklefs et al. 1986).

\section{Statistics}

Data for all variables were independent and approximately normal in distribution (KolmogorovSmirnov test; $P>.05$ ), so parametric statistics were employed for all tests. A rejection level $(\alpha)$ of .05 was used. Means are reported \pm 1 standard deviation, and regression constants are reported \pm 1 standard error. The effects of phylogenetic order, foraging mode, and oceanographic regime on activity-specific metabolic rates of free-living seabirds were determined by analysis of covariance (ANCOVA): using the statistical package SAS, slopes of the $\log _{10}-\log _{10}$ regressions of metabolism vs. body mass were compared; if slopes did not differ, equations were recalculated using the common slope, and the intercepts were compared.

\section{RESULTS}

\section{Metabolic rates of Northern Gannets}

Twenty-nine of 40 labeled gannets were recaptured a total of 46 times. Final ${ }^{18} \mathrm{O}$ levels of nine birds were too close to background for reliable measurements. FMRs of the remaining 20 birds averaged $4865 \pm 450$ $\mathrm{kJ} / \mathrm{d}$ (Table 2; mean mass $=3.21 \pm 0.21 \mathrm{~kg}$ ).

Comprehensive activity budgets were obtained for nine gannets. FMR increased with mean daily time spent flying according to the equation

$$
y=3452( \pm 606)+205( \pm 82) x,
$$

where $y$ is FMR in kilojoules per day and $x$ is time flying in hours per day $\left(r^{2}=0.47 ; P<.05\right.$; Fig. 1). When mean daily time spent on water was included in the regression the correlation coefficient did not increase significantly, and the correlation between FMR and time on water was also not significant. There is therefore no evidence that metabolism on water differs from metabolism at the nest. The intercept of the above regression equation $(3452 \pm 606 \mathrm{~kJ} / \mathrm{d}$ or $144 \pm 25$ $\mathrm{kJ} / \mathrm{h}$ ) is the predicted metabolic rate of a bird either at 
TABLE 1. Field (FMR), basal (BMR) and activity-specific metabolic rates of free-living seabirds studied using labeled water. BMRs were calculated as mass-specific BMR $\times$ mass.

\begin{tabular}{|c|c|c|c|c|c|c|}
\hline \multicolumn{2}{|c|}{ Species } & \multirow{2}{*}{$\begin{array}{c}\text { Mass } \\
(\mathrm{kg})\end{array}$} & \multirow{2}{*}{$\begin{array}{c}\text { FMR } \\
(\mathrm{kJ} / \mathrm{d})\end{array}$} & \multirow{2}{*}{$\begin{array}{r}\text { BMR } \\
(k J / d)\end{array}$} & \multirow{2}{*}{$\begin{array}{l}\text { At nest } \\
(\mathrm{kJ} / \mathrm{h})\end{array}$} & \multirow{2}{*}{$\begin{array}{c}\text { At sea } \\
(\mathrm{kJ} / \mathrm{h})\end{array}$} \\
\hline Common name & Scientific name & & & & & \\
\hline Adelie Penguin & Pygoscelis adeliae & $3.868 \pi$ & 4002 & 1039 & $\ldots$ & $\ldots$ \\
\hline Gentoo Penguin & P. рариа & 6.100 & 3584 & $\ldots$ & 83.4 & 307 \\
\hline King Penguin\# & Aptenodytes patagonicus & 13.000 & $5674^{* *}$ & $\ldots$ & $187+\dagger$ & 286 \\
\hline Macaroni Penguin & Eudyptes chrysolophus & 3.900 & 4380 & $\cdots$ & 57.6 & 281 \\
\hline Little Penguin & Eudyptula minor & 1.092 & $920 * *$ & 465 & 25.5 & 51.1 \\
\hline Jackass Penguin & Spheniscus demersus & 3.170 & 1945 & $\ldots$ & 52.1 & 207 \\
\hline Grey-headed Albatross & Diomedea chrysostoma & $3.665 \pi$ & $1729 * *$ & 718 & $42.9+\dagger$ & 100 \\
\hline Wandering Albatross & D. exulans & 8.417 & $2961^{* *}$ & 1817 & $107+\dagger$ & 140 \\
\hline Laysan Albatross & D. immutabilis & $3.067 \pi$ & $1802^{* *}$ & 607 & 60.3 & 89.9 \\
\hline Southern Giant Fulmar & Macronectes giganteus & 4.044 & 4443 & 976 & $\ldots$ & $\ldots$ \\
\hline Wedge-tailed Shearwater & Puffinus pacificus & 0.384 & 614 & 146 & $\cdots$ & $\cdots$ \\
\hline Wilson's Storm-Petrel & Oceanites oceanicus & $0.043 \pi$ & $119^{* *}$ & 44.0 & 3.38 & 6.54 \\
\hline Leach's Storm-Petrel & Oceanodroma leucorhoa & 0.045 & $89 * *$ & 41.9 & 2.10 & 5.38 \\
\hline Leach's Storm-Petrelł & O. leucorhoa & 0.046 & $121^{* *}$ & 42.9 & 3.42 & 6.63 \\
\hline Georgian Diving Petrel & Pelecanoides georgicus & 0.109 & $351 * *$ & 112 & $9.94 \ddagger \ddagger, \S \S$ & 19.3 \\
\hline Common Diving Petrel & P. urinatrix & 0.137 & $417^{* *}$ & 130 & $11.5 \ddagger \ddagger, \S \S$ & 23.2 \\
\hline Northern Gannet & Sula bassanus & 3.210 & 4865 & 742 & 144 & 250 \\
\hline Black-legged Kittiwake & Rissa tridactyla & 0.386 & $794 * *$ & 322 & 24.8 & 41.3 \\
\hline Sooty Tern & Sterna fuscata & $0.186 \pi$ & $241 * *$ & 87 & 5.90 & 14.2 \\
\hline Brown Noddy & Anous stolidus & 0.195 & 352 & 95 & $\ldots$ & $\ldots$ \\
\hline Common Murre & Uria aalge & 0.940 & 1789 & 348 & $\cdots$ & $\cdots$ \\
\hline Thick-billed Murre & U. lomvia & 0.834 & 1420 & 525 & $\cdots$ & $\cdots$ \\
\hline Black Guillemot & Cepphus grylle & 0.420 & 616 & $\ldots$ & $\ldots$ & $\ldots$ \\
\hline Least Auklet & Aethia pusilla & 0.083 & 358 & 116 & $\cdots$ & $\cdots$ \\
\hline
\end{tabular}

* Phylogenetic order: $\mathrm{S}=$ Sphensciformes, $\mathrm{Pr}=$ Procellariiformes, $\mathrm{Pe}=$ Pelecaniformes, $\mathrm{C}=$ Charadriiformes

† Oceanographic regime: $\mathrm{W}=$ warm water, $\mathrm{C}=$ cold water.

$\ddagger$ Foraging mode: $\mathrm{P}=$ pursuit diving, $\mathrm{G}=$ predominantly gliding flight, $\mathrm{F}=$ predominantly flapping flight.

$\S$ Figure symbol refers to abbreviations used in Figs. 3-5.

\| References: 1. Nagy 1987, 2. Kooyman et al. 1976, 3. Davis et al. 1989, 4. Davis and Kooyman 1984, 5. Costa et al. 1986, 6. Stahel and Nicol 1982, 7. Nagy et al. 1984, 8. Costa and Prince 1987, 9. Adams and Brown 1984, 10. Adams et al. 1986, 11. Brown and Adams 1984, 12. Grant and Whittow 1983, 13. Ellis 1984, 14. Obst et al. 1987, 15. Ricklefs et al. 1986, 16. W.A. Montevecchi and V. L. Birt-Friesen, personal observation, 17. Roby and Ricklefs 1986, 18. present study, 19. Gabrielsen et al. 1987, 20. Flint and Nagy 1984, 21. MacMillen et al. 1977, 22. Ellis et al. 1982, 23. Cairns et al. 1989, 24. Johnson and West 1975.

the nest or on water, and the slope $(205 \pm 82 \mathrm{~kJ} / \mathrm{h})$ represents the incremental cost of flying above maintenance costs. If the incremental cost of flying is assumed to be additive to metabolism at the nest (Flint and Nagy 1984, Nagy et al. 1984, Tatner and Bryant 1986), then total metabolism during flight is estimated to be $349 \pm 107 \mathrm{~kJ} / \mathrm{h}$.

The time that a seabird spends at sea may be considered to approximate time spent foraging. Durations of trips to sea by gannets range from $<1 \mathrm{~h}$ to several days. FMR did not vary with mean daily time spent at sea; however, labeled gannets spent variable amounts of night time at sea, when they were probably inactive (i.e., not foraging). This time may therefore be subtracted from total time spent at sea to obtain a closer approximation of time spent foraging. FMR increased significantly with mean daily diurnal time spent at sea $(y=4005[ \pm 350]+82.8[ \pm 37.4] x$, where $y$ is FMR in kilojoules per day and $x$ is diurnal time at sea in hours per day; $r^{2}=0.25 ; N=17 ; P<.05$; Fig. 2). If the total metabolic rate of a gannet during diurnal time at sea is assumed to be the sum of the intercept and slope of the above regression equation, then metabolism at sea is estimated to be $250 \pm 52 \mathrm{~kJ} / \mathrm{h}$.
BMRs of gannets at Cape St. Mary's and Funk Island were not statistically different (Student's $t$ test; $P>.10$ ) and averaged $701 \pm 131 \mathrm{~kJ} / \mathrm{d}(N=10$; range $=530$ $979 \mathrm{~kJ} / \mathrm{d}$; mean mass $=3.03 \pm 0.14 \mathrm{~kg}$ ), or $0.231 \pm$ $0.035 \mathrm{~kJ} \cdot \mathrm{g}^{-1} \cdot \mathrm{d}^{-1}$. BMR increased with mass on a $\log _{10^{-}}$ $\log _{10}$ scale $(\log y=1.53[ \pm 0.48]+2.73[ \pm 1.01] \log x$, where $y$ is BMR in kilojoules per day and $x$ is mass in $\left.\mathrm{kg} ; r^{2}=0.48 ; N=10 ; P<.05\right)$.

\section{DISCUSSION}

\section{Metabolic rates of Northern Gannets}

BMR of Northern Gannets is similar to the allometric estimate for a $3.03 \mathrm{~kg}$ nonpasserine bird (731 $\mathrm{kJ} / \mathrm{d}$; Lasiewski and Dawson $1967 ; t$ test; $P>.05)$, but lower than predicted either for a seabird $(849 \mathrm{~kJ} / \mathrm{d}$; Ellis $1984 ; t=3.58 ; P<.01$ ) or for a Pelecaniforme bird $(1018 \mathrm{~kJ} / \mathrm{d}$; Rahn and Whittow $1984 ; t=7.66 ; P$ $<.001)$. On the other hand, FMR and activity-specific metabolic rates are high compared both with measurements for other seabirds of similar mass (Table 1), and with allometric estimates for a $3.21 \mathrm{~kg}$ bird. For example, FMR is $1.6 \times$ as great as predicted by the equation of King (1974), and metabolism at the nest 
TABle 1. Continued.

\begin{tabular}{|c|c|c|c|c|c|}
\hline $\begin{array}{c}\text { Flying/ } \\
\text { diving } \\
(\mathrm{kJ} / \mathrm{h})\end{array}$ & Order* & $\begin{array}{l}\text { Ocean } \\
\text { regime }\end{array}$ & Mode $\ddagger$ & $\begin{array}{c}\text { Figure } \\
\text { symbol§ }\end{array}$ & $\begin{array}{l}\text { Refer- } \\
\text { ences }\end{array}$ \\
\hline$\ldots$ & $\mathrm{S}$ & $\mathrm{C}$ & $P$ & AP & 1,2 \\
\hline$\cdots$ & $\mathrm{S}$ & $\mathrm{C}$ & $\mathrm{P}$ & GP & 3 \\
\hline$\cdots$ & S & $\mathrm{C}$ & $\mathbf{P}$ & KP & 4 \\
\hline$\cdots$ & S & $\mathrm{C}$ & $\mathrm{P}$ & MP & 3 \\
\hline$\ldots$ & $\mathrm{S}$ & W & $\mathbf{P}$ & LP & 5,6 \\
\hline 310 & S & W & $\mathrm{P}$ & JP & 7 \\
\hline 131 & $\operatorname{Pr}$ & $\mathrm{C}$ & $\mathrm{G}$ & GA & 8,9 \\
\hline 178 & $\operatorname{Pr}$ & $\mathrm{C}$ & $\mathrm{G}$ & WA & 10,11 \\
\hline$\cdots$ & $\mathrm{Pr}$ & W & $\mathrm{G}$ & LA & 1,12 \\
\hline$\cdots$ & $\operatorname{Pr}$ & $\mathrm{C}$ & $\mathrm{G}$ & GF & 1,9 \\
\hline$\cdots$ & $\operatorname{Pr}$ & $\cdots$ & G & WS & 9,13 \\
\hline 6.54 & $\operatorname{Pr}$ & $\mathrm{C}$ & $\mathrm{G}$ & WSP & 14 \\
\hline$\ldots$ & $\operatorname{Pr}$ & W & $\mathrm{G}$ & LSP & 15 \\
\hline$\cdots$ & $\mathrm{Pr}$ & $\mathrm{C}$ & $\mathrm{G}$ & $\ldots$ & 16 \\
\hline$\ldots$ & $\mathrm{Pr}$ & $\mathrm{C}$ & $F$ & GDP & 17 \\
\hline$\ldots$ & $\mathrm{Pr}$ & $\mathrm{C}$ & $\mathrm{F}$ & CDP & 17 \\
\hline 349 & $\mathrm{Pe}$ & $\mathrm{C}$ & $\mathrm{F}$ & $\mathrm{NG}$ & 18 \\
\hline$\cdots$ & $\mathrm{C}$ & C & $\mathrm{F}$ & BK & 19 \\
\hline 16.9 & $\mathrm{C}$ & W & $\mathrm{F}$ & ST & 20,21 \\
\hline$\ldots$ & $\mathrm{C}$ & $\cdots$ & $\mathrm{F}$ & $\mathrm{BN}$ & 13,22 \\
\hline$\ldots$ & $\mathrm{C}$ & $\mathrm{C}$ & $\mathrm{F}$ & $\mathrm{CM}$ & 23 \\
\hline$\cdots$ & $\mathrm{C}$ & $\mathrm{C}$ & $\mathrm{F}$ & TM & 13,24 \\
\hline$\cdots$ & $\mathrm{C}$ & $\mathrm{C}$ & $F$ & $\mathrm{BG}$ & 13 \\
\hline$\ldots$ & $\mathrm{C}$ & $\mathrm{C}$ & $\mathrm{F}$ & LAK & 17 \\
\hline
\end{tabular}

I Mean for birds studied at sea and at the nest.

\# Studied using tritiated water.

** Assuming FMR is the mean of metabolic rates at sea and at the nest.

†† Used in calculation of FMR but not derived from labeled water studies, so not used in further analyses.

柱 Newfoundland. Values were not used in other analyses. $\S \S$ BMR $\times 2.13$ (mean multiple of BMR from Table 3 ).

is $2.7 \times$ as great as predicted by the equations of Kendeigh et al. (1977) for existence metabolism of a nonpasserine at $10^{\circ} \mathrm{C}$.

Handling of gannets for doubly labeled water had some adverse effects on behavior but did not appear to elevate FMR. For example, labeled gannets spent $42 \%$ of their time at the nest, whereas undisturbed gannets rearing chicks at Funk Island and other North American gannetries spent $50-65 \%$ of their time at the

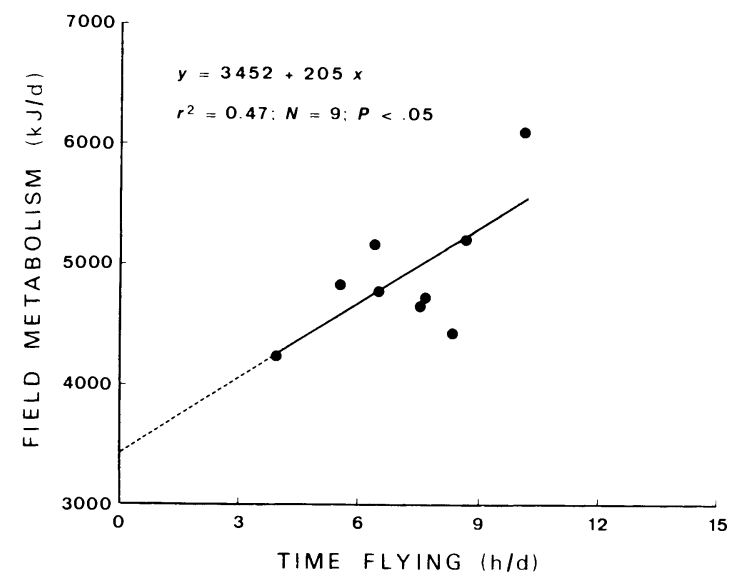

FIG. 1. Field metabolic rate as a function of mean daily time spent flying for nine Northern Gannets breeding at Funk Island, Newfoundland.

nest (Montevecchi and Porter 1980; W. A. Montevecchi and V. L. Birt-Friesen, personal observation). Labeled gannets probably spent time resting on water after handling, but if metabolic rates at the nest and on water are approximately equal, then FMR would not be measurably affected. Four chicks were lost during initial handling of parents, probably because of exposure. FMRs of gannets that (1) lost chicks, (2) spent $>65 \%$ of time at sea, and/or (3) did not return within $24 \mathrm{~h}$ of handling $(N=11)$ did not differ from those of apparently less disturbed birds ( $\mathrm{N}=9 ; t$ test; $P>.25)$. FMR was also not related to number of recaptures ( $t$ test; $P>.25$ ). FMR was also not related to number of recaptures ( $t$ test; $P>.25$ ) or recapture interval (Pearson correlation; $P>.10$ ).

J. A. Gessaman and K. A. Nagy (personal communication) found that metabolic rates during flight were $33 \%$ higher in pigeons wearing radio transmitters $(2.5 \%$ of body mass) than in controls. Activity recorders used in the present study weighed only $0.25 \%$ of a gannet's mass (Cairns et al. 1987). During flight, these timers were tucked with the feet in the undertail coverts, so would interfere with aerodynamics much less than would a transmitter strapped to the back or breast.

TABLE 2. Summary of doubly labeled water results for 20 Northern Gannets breeding at Funk Island. The discrepancy between field metabolism and metabolizable energy intake is addressed in the Discussion.

\begin{tabular}{lcccc}
\hline \hline & Mean & SD & Min & Max \\
\hline Mass (kg)* & 3.21 & 0.21 & 2.94 & 3.78 \\
Recapture interval (d) & 3.99 & 1.12 & 1.76 & 6.04 \\
Change in mass $(\mathrm{g} / \mathrm{d})$ & -34.6 & 52.5 & -121 & 41.9 \\
\% body water & 62.5 & 3.8 & 55.0 & 71.7 \\
$\mathrm{CO}_{2}$ production $\left(\mathrm{mL} \cdot \mathrm{g}^{-1} \cdot \mathrm{h}^{-1}\right)$ & 2.44 & 0.23 & 1.89 & 2.85 \\
Field metabolism $(\mathrm{kJ} / \mathrm{d})$ & 4865 & 450 & 3936 & 5794 \\
Water efflux $\left(\mathrm{mL} \cdot \mathrm{kg}^{-1} \cdot \mathrm{d}^{-1}\right)$ & 155 & 21 & 108 & 195 \\
Water influx $\left(\mathrm{mL} \cdot \mathrm{kg}^{-1} \cdot \mathrm{d}^{-1}\right)$ & 148 & & 105 & 195 \\
Metabolizable energy intake $(\mathrm{kJ} / \mathrm{d})$ & 3551 & 605 & 2550 & 4615 \\
$\quad($ sestimated from water influx) & & & & \\
\hline
\end{tabular}

* Mean of initial and final masses. 


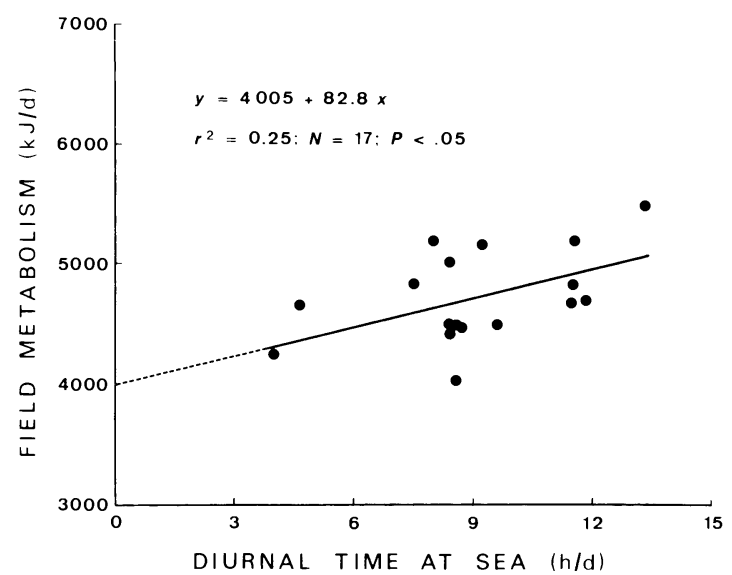

Fig. 2. Field metabolic rate as a function of mean daily diurnal time spent at sea for 17 Northern Gannets breeding at Funk Island, Newfoundland.

FMRs of gannets equipped with activity timers $(N=$ 13) did not differ from those of birds without timers $(N=7 ; t$ test; $P>.50)$.

Metabolizable energy intake of gannets estimated from water influx was $27 \%$ lower than FMR (Table 2). Calculations of water influx and ME involve several more assumptions than do calculations of FMR (Nagy 1980, Nagy and Costa 1980). For example, they require accurate evaluation of the preformed and metabolic water contents of the diet, and assume that little or no water is ingested. Ingestion of water by gannets is probably negligible, and water content of the diet was determined from regurgitated food collected at the time of doubly labeled water studies. The difference between ME and FMR may partly reflect an underestimate of the energy/water ratio of the diet, but more probably results from the utilization of body fat and/or food present in the gut from initial capture. Gannets tended to lose mass between captures (mean $=-29.9 \pm 52.5$ $\mathrm{g} / \mathrm{d} ; t=2.35 ; N=20 ; P<.05)$, and energy balance (ME - FMR) was positively correlated with change in mass $\left(r^{2}=0.44 ; N=20 ; P<.005\right)$. In other doubly labeled water studies, Jackass Penguins (Spheniscus demersus; Nagy et al. 1984), Little Penguins (Eudyptula minor; Costa et al. 1986), Common Diving Petrels (Pelecanoides urinatrix; Roby and Ricklefs 1986), and Black-legged Kittiwakes (Rissa tridactyla; Gabrielsen et al. 1987) also appeared to be in negative energy balance. Mass loss due to utilization of lipid stores is common in adult seabirds during reproduction. Common Murres studied using the present analytical procedure had a ME (also estimated from water influx) 9\% higher than FMR, indicating an approximate energy balance (D. K. Cairns, personal observation).

The high metabolic rates of Northern Gannets presumably result from foraging mode and climate. Although gannets are capable of prolonged gliding flight, they use flapping flight extensively while travelling to and from feeding sites (Nelson 1978; D. K. Cairns, personal observations), and their feeding mode (plunge diving) may require large energy expenditures (Ellis 1984). Air and sea surface temperatures are low at Funk Island in late August and September (both $\sim 5^{\circ}-10^{\circ} \mathrm{C}$; V. L. Birt-Friesen, personal observation [air]; Pickard and Emery 1982 [water]), and wet, windy, overcast, and foggy conditions often prevail. These factors, as well as the exposed nests and highly aggressive nestdefense activities of gannets (Nelson 1978; V. L. BirtFriesen and W. A. Montevecchi, personal observation) may all impose large metabolic costs (Ricklefs 1974, Davis and Kooyman 1984, Ellis 1984, Kersten and Piersma 1987). Black-legged Kittiwakes build open nests in cold environments, and metabolism at the nest in these birds is $1.8 \times$ as great as predicted by allometry (Gabrielsen et al. 1987; see Discussion: Metabolic Rates of Free-living Seabirds). FMR in kittiwakes was also found to be significantly higher during $24 \mathrm{~h}$ of strong winds than on calmer days (Gabrielsen et al. 1987). Metabolic rates of free-living Leach's Storm-Petrels (Oceanodroma leucorhoa) concurringly indicate that the Newfoundland climate demands a great deal of energy (Table 1): FMR of storm-petrels in Newfoundland (W. A. Montevecchi and V. L. Birt-Friesen, personal observation) was $1.4 \times$ as high as that of stormpetrels in New Brunswick (Ricklefs et al. 1986), and metabolic rate at the nest was $1.6 \times$ as high in Newfoundland.

\section{Metabolic rates of free-living seabirds}

To gain further insight into the causes of the high metabolic rates of Northern Gannets, we reviewed labeled-water studies of seabirds. FMRs and metabolic rates at the nest, at sea, and flying (or pursuit diving for penguins) of 23 species were obtained from the literature (Table 1). Not all FMR measurements were comparable since some studies were conducted during incubation and brooding, when seabirds spend $\approx 50 \%$ of their time at the nest and $\approx 50 \%$ at sea, and others were undertaken during courtship and postbrooding, when seabirds spend most of their time at sea. To make FMR measurements more comparable in this respect, values for birds studied during courtship and postbrooding were recalculated as the mean of rates at the nest and at sea. The allometric effects of foraging mode (pursuit diving, primarily flapping flight, primarily gliding flight), oceanographic regime (cold- or warmwater region), and phylogenetic order (Sphenisciformes, Procellariiformes, Charadriiformes) were analyzed by ANCOVA (see Methods: Statistics).

Metabolic rates at sea for free-living seabirds average $3.78 \pm 1.59 \times \operatorname{BMR}(N=11$; Table 3$)$, and have the allometric equation

$$
\log y=1.80 \pm 0.679 \log x,
$$

where $y$ is metabolism at sea in kilojoules per hour and $x$ is mass in kilograms $\left(r^{2}=0.91 ; N=15 ; P<.001\right.$; Table 4). Neither the slopes nor the intercepts of the 
TABLE 3. Activity-specific metabolic rates expressed as multiples of basal metabolism (BMR) and of metabolism at the nest for free-living seabirds.

\begin{tabular}{lccrcccc}
\hline \hline \multirow{2}{*}{$\begin{array}{c}\text { Metabolic } \\
\text { rate }\end{array}$} & \multicolumn{3}{c}{$\times$ BMR } & & \multicolumn{3}{c}{$\begin{array}{c}\text { metabolism } \\
\text { at nest }\end{array}$} \\
\cline { 2 - 4 } \cline { 6 - 8 } \cline { 6 - 8 } & Mean & SD & $N$ & & Mean & SD & $N$ \\
\hline Field & 3.29 & 1.22 & 18 & & 1.69 & 0.50 & 10 \\
At nest & 2.13 & 1.18 & 7 & & $\ldots$ & $\ldots$ & $\ldots$ \\
At sea & 3.78 & 1.59 & 11 & & 2.63 & 1.15 & 10 \\
Flying/diving & 5.25 & 3.49 & 5 & & 3.29 & 1.81 & 4 \\
\hline
\end{tabular}

allometric equations for cold- $(N=10)$ and warm- $(N$ $=5$ ) water seabirds differ; this similarity may result from thermal production during activity. The allometric equation for seabirds using primarily flapping flight (diving petrels, gannet, gulls; $N=5$ ) does not differ from that for pursuit divers (penguins; $N=5$ ), but when data for flapping fliers and pursuit divers are pooled, the intercept is significantly higher than that for seabirds using primarily gliding flight (albatrosses, storm-petrels; $N=5 ; F_{1,12}=11.4 ; P<.01$; Fig. 3; Table 4). (The intercept of the allometric equation for birds using gliding flight is also significantly lower than the intercept either for birds using flapping flight $\left[F_{1,7}\right.$ $=9.88 ; P<.05]$ or for pursuit divers $\left[F_{1,7}=8.51 ; P\right.$ $<.05]$ ). Furness and Monaghan (1987) proposed that foraging metabolism may account for the scarcity of pursuit divers in the tropics, where food is widely dispersed. This hypothesis is supported by the present results. Metabolic rate at sea for the Sooty Tern appears low for a flapping flier, but terns have high aspect ratios and may use more gliding flight than previously estimated (Flint and Nagy 1984; A. W. Diamond, personal communication). Sample sizes were too small for analyses according to phylogenetic order.

Only six measurements of metabolic rates during

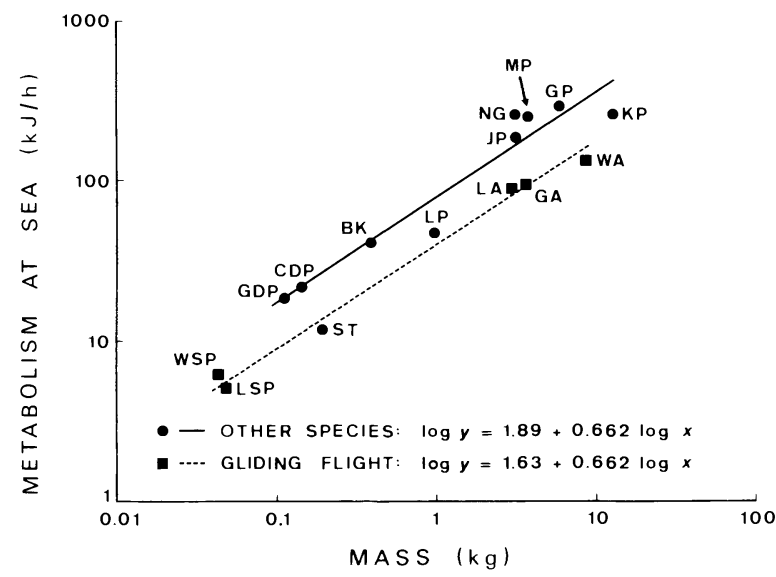

FIG. 3. Allometry of metabolic rates at sea for 15 seabird species, studied with tritiated (King Penguin) or doubly labeled (all others) water. Regression lines from ANCOVA (Table 4). See Table 1 for species symbols and references.

flight (or pursuit diving) are available for free-living seabirds (Table 1). These values average $5.25 \pm 3.49$ $\times \operatorname{BMR}(N=5$; Table 3$)$ and have the allometric equation

$$
\log y=1.86 \pm 0.748 \log x
$$

where $y$ is metabolism during flight in kilojoules per hour and $x$ is mass in kilograms $\left(r^{2}=0.89 ; N=6 ; P\right.$ $<.01$; Fig. 4; Table 4). Due to the small sample size, this equation is considered tentative. No conclusions can be drawn regarding the effect of foraging mode on flight metabolism, but values for the albatrosses, which have a special winglock mechanism that probably conserves energy during flight (Furness and Monaghan 1987), are lower than the allometric estimates (Fig. 4).

Metabolic rates at the nest of free-living seabirds

TABLE 4. Statistics for $\log _{10}-\log _{10}$ regressions of field metabolic rate and activity-specific metabolic rates against mass (in $\mathrm{kg}$ ) for free-living seabirds. Equations for all seabirds are from least squares regressions; all other equations are from ANCOVA, using common slopes.

\begin{tabular}{|c|c|c|c|c|c|}
\hline Group & Intercept (SE) & Slope (SE) & $N$ & $r^{2}$ & $P$ \\
\hline \multicolumn{6}{|l|}{ Field metabolic rate $(\mathrm{kJ} / \mathrm{d})$} \\
\hline All seabirds & $3.08(0.03)$ & $0.667(0.045)$ & 23 & 0.91 & $<.001$ \\
\hline Cold water seabirds & $3.13(0.03)$ & $0.646(0.040)$ & 5 & 0.94 & $<.001$ \\
\hline Warm water seabirds & $2.90(0.06)$ & $0.646(0.040)$ & 16 & 0.94 & $<.001$ \\
\hline Seabirds using flapping flight & $3.19(0.05)$ & $0.726(0.044)$ & 10 & 0.94 & $<.001$ \\
\hline Seabirds not using flapping flight & $3.00(0.04)$ & $0.726(0.044)$ & 13 & 0.94 & $<.001$ \\
\hline Cold water seabirds using flapping flight & $3.24(0.05)$ & $0.727(0.039)$ & 8 & 0.95 & $<.001$ \\
\hline Other seabirds & $2.99(0.04)$ & $0.727(0.039)$ & 13 & 0.95 & $<.001$ \\
\hline \multicolumn{6}{|l|}{ Metabolic rate at the nest $(\mathrm{kJ} / \mathrm{h})$} \\
\hline All seabirds & $1.45(0.06)$ & $0.737(0.074)$ & 10 & 0.93 & $<.001$ \\
\hline \multicolumn{6}{|l|}{ Metabolic rate at sea $(\mathrm{kJ} / \mathrm{h})$} \\
\hline All seabirds & $1.80(0.05)$ & $0.679(0.058)$ & 15 & 0.91 & $<.001$ \\
\hline Seabirds using gliding flight & $1.63(0.06)$ & $0.662(0.044)$ & 5 & 0.95 & $<.001$ \\
\hline Seabirds not using gliding flight & $1.89(0.04)$ & $0.662(0.044)$ & 10 & 0.95 & $<.001$ \\
\hline \multicolumn{6}{|c|}{ Metabolic rate during flight or pursuit diving $(\mathrm{kJ} / \mathrm{h})$} \\
\hline All seabirds & $1.86(0.11)$ & $0.748(0.132)$ & 6 & 0.89 & $<.01$ \\
\hline
\end{tabular}




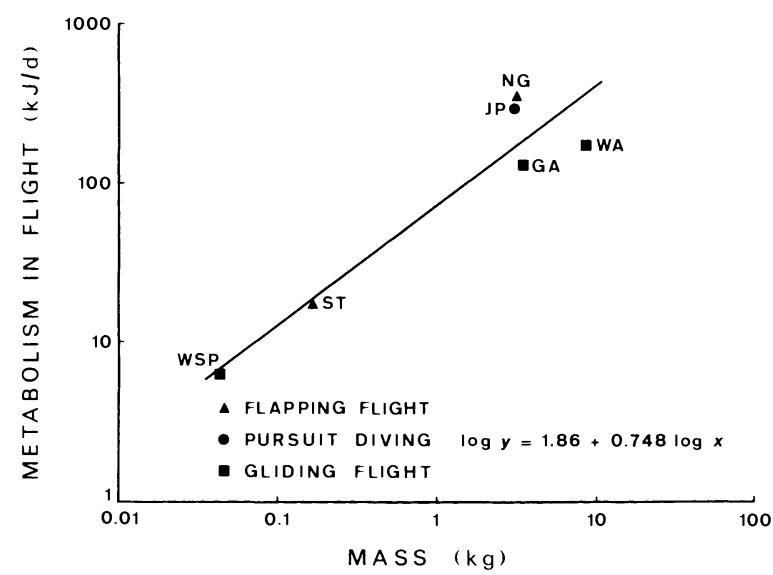

FIG. 4. Allometry of metabolic rates during flight or pursuit diving of 6 seabird species, studied with doubly labeled water. Regression line derived by the method of least squares (Table 4). See Table 1 for species symbols and references.

average $2.13 \pm 1.18 \times \operatorname{BMR}(N=7$; Table 3$)$, and have the allometric equation

$$
\log y=1.45+0.737 \log x,
$$

where $y$ is metabolism at the nest in kilojoules per hour and $x$ is mass in kilograms $\left(r^{2}=0.93 ; N=10 ; P<\right.$ .001 ; Fig. 5; Table 3). The allometric equations for birds in cold- $(N=5)$ vs. warm- $(N=5)$ water regions do not differ. Sample sizes were too small for analyses according to foraging mode or phylogenetic order. Metabolic rate on water has been measured in only one other free-ranging seabird: Jackass Penguins are similar in size to gannets $(3.17 \mathrm{~kg})$ and their estimated metabolism $(122 \mathrm{~kJ} / \mathrm{h})$ is also similar to that of gannets $(t$ test; $P>.05)$.

FMRs of free-ranging seabirds average $3.29 \pm 1.22$ $\times \operatorname{BMR}(N=18$; Table 3$)$, and have the allometric equation

$$
\log y=3.08+0.667 \log x,
$$

where $y$ is FMR in kilojoules per day and $x$ is mass in kilograms $\left(r^{2}=0.92 ; N=23 ; P<.001\right.$; Table 4$)$. This equation does not differ from those of King (1974) for birds in general or Nagy (1987) for seabirds, although it involves a larger number of measurements on freeliving birds. The allometric equations for birds in separate orders do not differ, but the intercept for seabirds occurring in cold-water regions $(N=16)$ is significantly higher than that for birds in warm-water regions $(N=$ 5; $F_{1,18}=10.6 ; P<.01$; Fig. 6A; Table 4), which indicates that they have higher energy demands. The allometric equation for seabirds that forage by pursuit diving $(N=6)$ does not differ from the equation for seabirds that use primarily gliding flight $(N=7)$, but the intercept of the equation for birds in both groups combined is significantly lower than the intercept for seabirds using primarily flapping flight $\left(N=10 ; F_{1,20}\right.$ $=7.79 ; P<.05 ;$ Fig. $6 \mathrm{~B}$; Table 4 ). (The intercept of the equation for flapping fliers is also higher than the intercept for gliding fliers $\left[F_{1,14}=7.58 ; P<.05\right]$, and tends to be higher than that for pursuit divers, although this difference does not attain statistical significance $\left[F_{1,13}=3.45 ; .10>P>.05\right]$.) The similarity in FMRs of seabirds using gliding flight and pursuit diving, despite differences in metabolic rates at sea (see above), may result from the relative proportions of time spent flying and diving: many gliding fliers spend all or most of the time that they are at sea in flight (e.g., Wilson's Storm-Petrel [Oceanites oceanicus], Obst et al. 1987; Grey-headed Albatrosses [Diomedea chrysostoma], Prince and Francis 1984), whereas penguins probably spend only a small part of each trip in pursuit diving (e.g., Jackass Penguins, Nagy et al. 1984). These results also concur with hypotheses about ceilings on FMRs of free-ranging animals (e.g., Drent and Daan 1980, Ellis 1984).

Based on the ANCOVA results for FMR, species can be grouped into three categories according to both oceanographic regime and foraging mode: (1) cold-water seabirds using primarily flapping flight $(N=10)$; (2) cold-water seabirds not using primarily flapping flight $(N=8)$, and warm-water seabirds using primarily flapping flight $(N=1)$; and (3) warm-water seabirds not using primarily flapping flight $(N=4)$. The allometric equations for Groups 2 and 3 do not differ, but when data for birds in these groups are pooled, the intercept is significantly lower than that for high-latitude seabirds using flapping flight $\left(F_{1,18}=17.0 ; P<.001\right.$; Table 4; Fig. 6C). (The intercept of the equation for birds in Group 1 is also significantly higher than the intercepts for birds in Group $2\left[F_{1,14}=8.09, P<.05\right]$ or Group $3\left[F_{1,9}=43.1 ; P<.001\right]$.) FMRs of free-living seabirds can therefore be described by two allometric equations: for high-latitude seabirds that use flapping flight,

$$
\log y=3.24+0.727 \log x,
$$

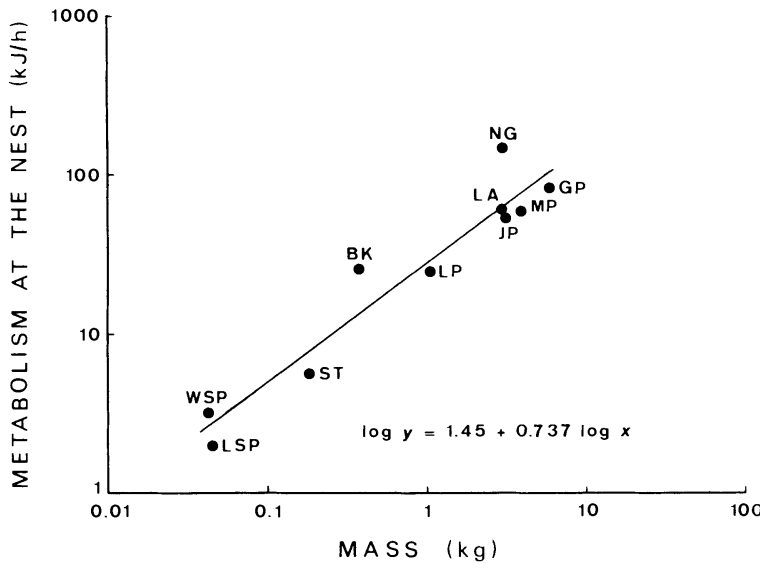

FIG. 5. Allometry of metabolic rates at the nest of 10 seabird species, studied with doubly labeled water. Regression line derived by the method of least squares (Table 4). See Table 1 for species symbols and references. 
$\left(r^{2}=0.95 ; P<.001\right.$; Table 4$)$; for all other seabirds,

$$
\log y=2.99+0.727 \log x,
$$

$\left(r^{2}=0.95 ; P<.001 ;\right.$ Table 4$)$.

Our observations that FMR is elevated in cold-water seabirds, and that FMR and metabolism at sea are higher in flapping fliers than in gliding fliers concur with the trends reported by Ellis (1984) for BMR. Rahn and Whittow (1984) found that BMRs of Procellariiformes birds are lower than those of other seabirds, but we found no differences in scaling of either FMR or metabolic rate at sea between Procellariiformes birds and other species.

\section{Conclusions}

FMR and metabolic rate at sea of Northern Gannets are 1.9 and $1.8 \times$ as high respectively as the general allometric estimates in Table 4, but are only 1.2 and $1.5 \times$ as high respectively as the allometric estimates for cold water seabirds using flapping flight. The remaining difference between observed and predicted rates may result from handling, a $10-20 \%$ overestimate by our doubly labeled water assay, and/or unknown factors.

FMR and activity-specific metabolic rates of different animals often are correlated directly with BMR (Ricklefs 1974, Kendeigh et al. 1977, Drent and Daan 1980, Ellis 1984), and several researchers have speculated on a maximum sustainable metabolic rate, generally $\approx 4 \times$ BMR (Drent and Daan 1980, Ellis 1984). Metabolic limitation could result from such factors as the capacity of tissues such as flight muscle to mobilize energy reserves, or rates of digestion and assimilation (Ricklefs 1974, Walsberg 1983, Diamond et al. 1986, Krebs and Harvey 1986). Animals that engage in costly modes of locomotion and/or live in cold environments have elevated FMRs (Fig. 6, Table 4), and most also have high BMRs (Weathers 1979, Hails 1983, Ellis 1984; Table 1). FMRs of 18 species in Table 2 are highly correlated with BMR $(y=326[ \pm 340]+$ $2.57[ \pm 0.52] x$, where $y$ is FMR in kilojoules per day and $x$ is BMR in kilojoules per day; $r^{2}=0.60 ; P<$ $.001)$. In contrast, BMRs of gannets are apparently not elevated, despite high field and activity-specific metabolic rates, and FMR averages $6.6 \times$ BMR. Unlike cold-water seabirds such as alcids, gannets winter at low latitudes and probably evolved in tropical or temperate areas (Nelson 1978), so may have retained a low BMR. BMR and thermoregulation in the gannet require further study.

Estimates of gannet population energetics using conventional extrapolations of BMR (Montevecchi et al. 1984) have underestimated fish consumption by $>300 \%$, largely because of thermoregulatory costs (Montevecchi et al. 1988). Field and activity-specific metabolic rates of gannets expressed as multiples of metabolism at the nest, which includes thermoregu-

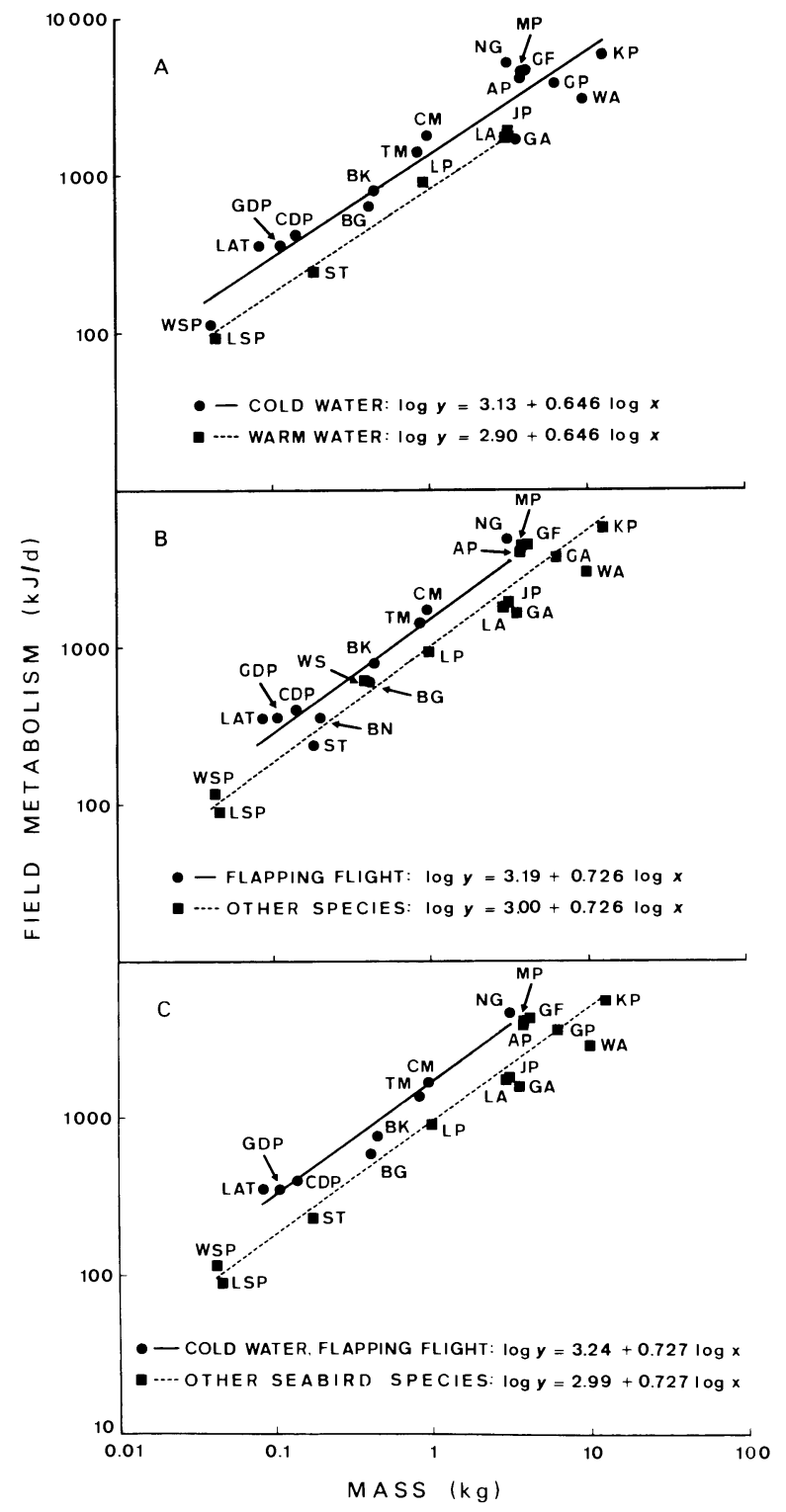

FIG. 6. Allometry of field metabolic rates of 23 seabird species, studied with tritiated (King Penguin) or doubly labeled (all others) water. Regression lines from ANCOVA (Table 4). See Table 1 for species symbols and references.

latory costs, are similar to those of other species (Table 5), and FMRs of 10 species of seabirds listed in Table 1 are highly correlated with metabolism at the nest $(y$ $=186[ \pm 386]+1.53[+0.26] x$, where $y$ is FMR in kilojoules per day and $x$ is metabolism at the nest in kilojoules per day; $\left.r^{2}=0.82 ; P<.001\right)$. Although this relationship may result partially from nonindependence of the metabolism measurements (e.g., FMRs of some species were assumed to be the mean of metabolic rates at sea and at the nest), it may be useful to field ecologists when measurement of metabolism at the nest is easier than measurement of BMR. The present paper also presents a method of analysis of metabolic 
TABLE 5. Field metabolic rate (FMR) and metabolic rates during flight (or pursuit diving) and at sea expressed as multiples of metabolism at the nest for free-living seabirds. See Table 1 for scientific names and for references.

\begin{tabular}{lccc}
\hline \hline \multicolumn{1}{c}{ Species } & FMR & $\begin{array}{c}\text { Flying/ } \\
\text { diving }\end{array}$ & At sea \\
\hline Macaroni Penguin & 3.1 & $\ldots$ & 4.9 \\
Little Penguin & 1.5 & $\ldots$ & 2.0 \\
Jackass Penguin & 1.6 & 5.9 & 4.0 \\
Laysan Albatross & 1.2 & $\ldots$ & 1.5 \\
Northern Gannet & 1.4 & 2.4 & 1.9 \\
Wilson's Storm-Petrel & 1.5 & 1.9 & 1.9 \\
Leach's Storm-Petrel & 1.8 & $\ldots$ & 2.6 \\
Black-legged Kittiwake & 1.3 & $\ldots$ & 1.7 \\
Sooty Tern & 1.7 & 2.9 & 2.4 \\
\hline
\end{tabular}

rates according to mass, activity pattern (at the nest, at sea or both), oceanographic regime, and foraging mode; this method permits more accurate estimation of metabolic rates than was previously possible. Ecological energetics models may therefore gain accuracy if metabolic rates are either expressed as multiples of metabolism at the nest (Table 3 ) or are calculated from allometric equations appropriate for the species' activity pattern, foraging mode, and oceanographic regime. Further measurements of metabolic rates of seabirds at sea and in flight are necessary to understand better the metabolic consequences of different flight modes. More studies of metabolic rates at the nest are also needed to understand more fully the thermoregulatory costs of free-living animals.

\section{ACKNOWLEDGMENTS}

We thank K. A. Bredin and W. Sturge for field assistance; G. Herzberg for laboratory facilities; D. C. Schneider, G. R. Skanes, and R. E. Dillinger, Jr. for statistical help; and T. P. Birt, R. E. Ricklefs, D. C. Schneider, G. L. Kooyman, and two anonymous reviewers for helpful criticisms of earlier versions of the manuscript. The Newfoundland and Labrador Wildlife Division provided permission to work at Funk Island and Cape St. Mary's (Provincial Ecological Reserves). K. A. Nagy and P. Tatner generously collaborated in laboratory validations of our methods and $P$. Tatner shared unpublished data. Funding and equipment were provided by the Natural Sciences and Engineering Research Council of Canada (Individual Operating Grant Numbers A0687 to W. A. Montevecchi and A2644 to S. A. Macko, and postgraduate scholarship to V. L. Birt), Fisheries and Oceans Canada 1985 anc 1986 Subventions (D. K. Cairns and W. A. Montevecchi), and the Department of Psychology and the Newfoundland Institute for Cold Ocean Science (Memorial University of Newfoundland). This is report number 149 from the Newfoundland Institute for Cold Ocean Science.

\section{Literature Cited}

Adams, N. J., and C. R. Brown. 1984. Metabolic rates of sub-Antarctic Procellariiformes: a comparative study. Comparative Biochemistry and Physiology 77A:169-173.

Adams, N. J., C. R. Brown, and K. A. Nagy. 1986. Energy expenditure of free-ranging Wandering Albatrosses Diomedea exulans. Physiological Zoology 59:583-591.

Birt, V. L. 1987. Parental activity budgets and energy expenditures of Northern Gannets (Sula bassanus). Thesis.
Memorial University of Newfoundland, St. John's, Newfoundland, Canada.

Birt, V. L., and D. K. Cairns. 1987. Kleptoparasitic interactions of Arctic Skuas Stercorarius parasiticus and Black Guillemots Cepphus grylle in northeastern Hudson Bay, Canada. Ibis 129:190-196.

$\rightarrow$ Brown, C. R., and N. J. Adams. 1984. Basal metabolic rate and energy cost of incubation in the Wandering Albatross (Diomedea exulans). Condor 86:182-186.

Buttemer, W. A., A. M. Hayworth, W. W. Weathers, and K. A. Nagy. 1986. Time-budget estimates of avian energy expenditure: physiological and meteorological considerations. Physiological Zoology 59:131-149.

$\rightarrow$ Cairns, D. K., K. A. Bredin, V. L. Birt, and W. A. Montevecchi. 1987. Electronic activity recorders for aquatic wildlife. Journal of Wildlife Management 51:395-399.

Cairns, D. K., W. A. Montevecchi, V. L. Birt-Friesen, and S. A. Macko. 1989. Energy expenditures, activity budgets, and prey harvest of breeding Common Murres. Studies in Avian Biology, in press.

Costa, D. P., P. Daan, and W. Disher. 1986. Energy requirements of free ranging Little Penguin, Eudyptula minor. Comparative Biochemistry and Physiology 85A:135-138.

Costa, D. P., and P. A. Prince. 1987. Foraging energetics of grey-headed albatrosses Diomedea chrysostoma at Bird Island, South Georgia. Ibis 129:190-196.

Davis, R. W., J. P. Croxall, and M. J. O'Connell. 1989. The reproductive energetics of Gentoo and macaroni penguins at South Georgia. Journal of Animal Ecology 58, in press.

Davis, R. W., and G. L. Kooyman. 1984. Free-ranging energetics of penguins. Pages $245-253$ in G. C. Whittow and H. Rahn, editors. Seabird energetics. Plenum, New York, New York, USA.

Diamond, J. M., W. H. Karasov, D. Phan, and F. L. Carpenter. 1986. Digestive physiology is a determinant of foraging bout frequency in hummingbirds. Nature 320:6263.

Drent, R. H., and S. Daan. 1980. The prudent parent: energetic adjustments in avian breeding. Ardea 68:225-252.

Ellis, H. I. 1984. Energetics of free-ranging seabirds. Pages 203-234 in G. C. Whittow and H. Rahn, editors. Seabird energetics. Plenum, New York, New York, USA.

Ellis, H. I., M. Maskrey, T. N. Pettit, and G. C. Whittow. 1982. Temperature regulation in Hawaiian brown noddies (Anous stolidus pileatus). Physiologist 25:279.

Flint, E. N., and K. A. Nagy. 1984. Flight energetics of freeliving Sooty Terns. Auk 101:288-294.

Furness, R. W. 1978. Energy requirements of seabird communities: a bioenergetics model. Journal of Animal Ecology 47:39-53.

- 1982. Competition between fisheries and seabird communities. Advances in Marine Biology 20:225-307.

Furness, R. W., and P. Monaghan. 1987. Seabird ecology. Chapman and Hall, New York, New York, USA.

Gabrielsen, G. W., F. Mehlum, and K. A. Nagy. 1987. Daily energy expenditure and energy utilization of free-ranging Black-legged Kittiwakes. Condor 89:126-132.

Grant, G. S., and G. C. Whittow. 1983. Metabolic cost of incubation in the Laysan albatross and Bonin petrel. Comparative Biochemistry and Physiology 74A:77-82.

$\rightarrow$ Hails, C. J. 1983. The metabolic rate of tropical birds. Condor 85:61-65.

$\rightarrow$ Johnson, S. R., and G. C. West. 1975. Growth and development of heat regulation in nestlings, and metabolism of adult common and thick-billed murres. Ornis Scandinavica 6:109-115.

Kendeigh, S. C., V. R. Dol'nik, and V. M. Gavrilov. 1977. Avian energetics. Pages 127-204 in J. Pinowski and S. C. Kendeigh, editors. Granivorous birds in ecosystems. Cambridge University Press, Cambridge, England.

Kersten, M., and T. Piersma. 1987. High levels of energy 
expenditure in shorebirds; metabolic adaptations to an energetically expensive way of life. Ardea 75:175-187.

King, J. R. 1974. Seasonal allocation of time and energy resources in birds. Pages 4-85 in R. A. Paynter, Jr., editor. Avian energetics. Nuttall Ornithological Club, Harvard University, Cambridge, Massachusetts, USA.

Kooyman, G. L., J. O. Billups, and W. D. Farwell. 1983 $\rightarrow$ Two recently developed recorders for monitoring diving activity of marine birds and mammals. Pages 197-214 in A. J. MacDonald and I. G. Priede, editors. Experimental biology at sea. Academic Press, London, England.

Kooyman, G. L., R. L. Gentry, W. P. Bergman, and H. T. Hammel. 1976. Heat loss in penguins during immersion and compression. Comparative Biochemistry and Physiology 54A:75-80.

Krebs, J. R., and P. H. Harvey. 1986. Busy doing nothing $\rightarrow$ efficiently. Nature 320:18-19.

Lasiewski, R. C., and W. R. Dawson. 1967. A re-examination of the relation between standard metabolic rate and body weight in birds. Condor 69:238-242.

$\rightarrow$ MacMillen, R. E., G. C. Whittow, E. A. Christopher, and R. J. Ebisu. 1977. Oxygen consumption, evaporative water loss and body temperature in the Sooty Tern. Auk 94:7279.

Montevecchi, W. A., V. L. Birt, and D. K. Cairns. 1988. Dietary changes of seabirds associated with local fisheries failures. Biological Oceanography 5:153-159.

Montevecchi, W. A., and J. M. Porter. 1980. Parental investments by seabirds at the breeding area with emphasis on northern gannets, Morus bassanus. Pages 323-365 in J. Burger, B. L. Olla, and H. E. Winn, editors. Behavior of marine animals. Volume IV. Plenum, New York, New York, USA.

$\rightarrow$ Montevecchi, W. A., R. E. Ricklefs, I. R. Kirkham, and D. Gabaldon. 1984. Growth energetics of nestling Northern Gannets (Sula bassanus). Auk 101:334-341.

Nagy, K. A. 1980. $\mathrm{CO}_{2}$ production in animals: analysis of potential errors in the doubly labeled water method. American Journal of Physiology 238:R466-473.

1983. The doubly labeled water $\left({ }^{3} \mathrm{HH}^{18} \mathrm{O}\right)$ method $\rightarrow$ a guide to its use. University of California at Los Angeles Publication, Los Angeles, California, USA.

1987. Field metabolic rate and food requirement scaling in mammals and birds. Ecological Monographs 57: $111-128$

Nagy, K. A., and D. P. Costa. 1980. Water flux in animals: analysis of potential errors in the tritiated water method American Journal of Physiology 238:R454-465.

$\rightarrow$ Nagy, K. A., W. R. Siegfried, and R. P. Wilson. 1984. Energy utilization by free-ranging Jackass Penguins, Spheniscus demersus. Ecology 65:1648-1655.

Nelson, J. B. 1978. The gannet. Buteo Books, Vermillion, South Dakota, USA.

Nettleship, D. N., and G. Chapdelaine. 1988. Population size and status of the Northern Gannet in North America. Journal of Field Ornithology 59:120-127.
Obst, B. S., K. A. Nagy, and R. E. Ricklefs. 1987. Energy utilization in Wilson's storm-petrel (Oceanites oceanicus). Physiological Zoology 60:200-210.

Pickard, G. L., and W. J. Emery. 1982. Descriptive physical oceanography, an introduction. Pergamon, Oxford, England.

Prince, P. A., and M. D. Francis. 1984. Activity budgets of foraging Grey-headed Albatrosses. Condor 86:297-300.

Rahn, H., and G. C. Whittow. 1984. Introduction. Pages 1-32 in G. C. Whittow and H. Rahn, editors. Seabird energetics. Plenum, New York, New York, USA.

Ricklefs, R. E. 1974. Energetics of reproduction in birds. Pages 152-297 in R. A. Paynter, Jr., editor. Avian energetics. Nuttall Ornithological Club, Harvard University, Cambridge, Massachusetts, USA.

Ricklefs, R. E., D. Gabaldon, and W. A. Montevecchi. 1984. Postnatal development of the northern gannet Sula bassanus, and the general relationship between growth rate and adult size in birds. Ornis Scandinavica 15:204-210.

Ricklefs, R. E., D. D. Roby, and J. B. Williams. 1986. Daily energy expenditure of adult Leach's storm-petrels during the nesting cycle. Physiological Zoology 59:649-660.

Roby, D. D., and R. E. Ricklefs. 1986. Energy expenditure in adult least auklets and diving petrels during the chickrearing period. Physiological Zoology 59:661-678.

Stahel, C.D., and S. C. Nicol. 1982. Temperature regulation in the little penguin, Eudyptula minor, in air and water. Journal of Comparative Physiology 148:93-100.

Tatner, P., and D. M. Bryant. 1986. Flight cost of a small passerine measured using doubly labeled water: implications for energetics studies. Auk 103:169-180.

Tucker, V. A. 1973. Bird metabolism during flight. Journal of Experimental Zoology 58:689-709.

Walsberg, G. E. 1983. Ecological energetics: what are the questions. Pages 135-158 in A. H. Brush and G. A. Clark, Jr., editors. Perspectives in ornithology. Cambridge University Press, Cambridge, England.

Weathers, W. W. 1979. Climatic adaptation in avian standard metabolic rate. Oecologia (Berlin) 42:81-89.

Weathers, W. W., W. A. Buttemer, A. M. Hayworth, and K. A. Nagy. 1984. An evaluation of time-budget estimates of daily energy expenditure in birds. Auk 101:459-472.

Wiens, J. A. 1984. Modelling the energy requirements of seabird populations. Pages 255-284 in G. C. Whittow and H. Rahn, editors. Seabird energetics. Plenum, New York, New York, USA.

Wilson, R. P., and C. A. R. Bain. 1984. An inexpensive speed meter for penguins at sea. Journal of Wildlife Management 48:1360-1364.

Wood, R. A., K. A. Nagy, N. S. MacDonald, S. T. Wakakuwa, R. J. Beckman, and H. Kaaz. 1975. Determination of oxygen-18 in water contained in biological samples by charged particle activation. Analytical Chemistry 47:646650 . 